\title{
MARKETING POLITIK PEMENANGAN JOKOWI-JK PADA PEMILIHAN PRESIDEN TAHUN 2014
}

\author{
Linayati Lestari, Alpikri \\ Ilmu Pemerintahan Fakultas Ilmu Sosial dan Ilmu Politik \\ Universitas Riau Kepulauan \\ linayatilestari@yahoo.com,alpikri@gmail.com
}

\begin{abstract}
Election of President and Vice President of the Republic of Indonesia Year 2014 (2014 presidential election) was held on July 9, 2014 to elect the President and Vice President of Indonesia for the period 2014-2019. Efforts towards the award process, the politicians do the propaganda and agitation against the people (voters) in order that the candidate from the party that wins diusungnya at a general election. This is where the strategy is needed as a vehicle for political dynamic development and as a means to the goal in question.

The problems of research that is how political marketing Joko Widodo-Jusuf Kalla on winning the presidential election of 2014 in the city of Batam. The purpose of this study was to determine political marketing Joko Widodo - Jusuf Kalla on winning the presidential elections in 2014 in the city of Batam. The benefits of this research is theoretically and practically.

The method used in this research is using the qualitative approach with descriptive approach. Data collection techniques used in this study is observation, interview and dokumnetasi.

The results of the study describes the Winning Strategy Joko Widodo-Jusuf Kalla On Presidential Elections of 2014 in the city of Batam (Case Study Sagulung Subdistrict, District Batam City and District Bengkong). Victory Joko Widodo-Jusuf Kalla in the 2014 presidential election in Batam will be seen from the process of political marketing that product offered, promotion is done, the selling price, a prioritized and market segmentation. From the research that has been done can be concluded that the victory of Joko Widodo-Jusuf Kalla at the presidential election in 2014 in the city of Batam, influenced by products that offer is to build elektabilitas candidate in the eyes of society, promotion done is to convey the benefits of its products to the public in the form of banners, billboards, tabloids and pamphlets. Selling prices here focuses on the psychological price to image nationally be a price to pay. Place priority aims to establish communication with the voters as the campaign must touch all levels of society. Market segmentation is done is to investigate complaints of people who are not uniform. To get the victory Joko Widodo-Jusuf Kalla, the more accurate the 2014 presidential election should be held for further research in terms of other strategies.
\end{abstract}

Keywords: election, marketing, strategy, politic, presidential election

\begin{abstract}
Abstrak
Pemilihan Umum Presiden dan Wakil Presiden Republik Indonesia Tahun 2014 (Pilpres 2014) dilaksanakan pada tanggal 9 Juli 2014 untuk memilih Presiden dan Wakil Presiden Indonesia untuk periode 2014-2019. Upaya menuju proses pemenangan, para politisi melakukan propaganda dan agitasi terhadap masyarakat (pemilih) agar calon dari partai yang diusungnya menang pada saat pemilihan umum. Di sinilah strategi dibutuhkan sebagai wahana perkembangan dinamika politik dan sebagai alat menuju cita-cita yang dimaksud.

Rumusan masalah dari penelitian yaitu bagaimana marketing politik Joko Widodo-Jusuf Kalla pada pemenangan pemilihan Presiden Tahun 2014 di Kota Batam. Tujuan dari penelitian ini
\end{abstract}


adalah untuk mengetahui marketing politik Joko Widodo-Jusuf Kalla pada pemenangan pemilihan presiden tahun 2014 di Kota Batam. Manfaat dari penelitian ini yaitu secara teoritis dan secara praktis.

Metode yang digunakan dalam penelitian ini adalah menggunkan pendekatan kualitatif dengan pendekatan deskriptif. Teknik pengumpulan data yang digunakan dalam penelitian ini adalah observasi, wawancara dan dokumnetasi.

Kemenangan Joko Widodo-Jusuf Kalla pada Pilpres 2014 di Kota Batam akan dilihat dari proses marketing politik yaitu produk yang ditawarkan, promosi yang dilakukan, harga jual, tempat yang diprioritaskan dan segmentasi pasar. Dari penelitian yang telah dilakukan dapat disimpulkan bahwa kemenangan Joko Widodo-Jusuf Kalla pada pilpres 2014 di Kota Batam, di pengaruhi oleh produk yang tawarkan adalah untuk membangun elektabilitas calon dimata masyarakat, Promosi yang dilakukan adalah untuk menyampaikan keunggulan produknya kepada masyarakat baik berupa spanduk, baliho, tabloid dan pamplet. Harga Jual disini menitik beratkan pada harga secara psikologis hingga citra secara nasional menjadi harga yang harus dibayar. Tempat yang diprioritaskan bertujuan untuk membangun komunikasi dengan pemilih karena kampanye harus menyentuh semua lapisan masyarakat. Segmentasi pasar dilakukan adalah untuk mengetahui keluhan-keluhan masyarakat yang tidak seragam. Untuk mendapatkan proses kemenangan Joko Widodo-Jusuf Kalla yang lebih akurat pada pilpres 2014 perlu diadakan penelitian lebih lanjut yang ditinjau dari strategi lainnya.

Kata Kunci : Pemilihan Umum, Marketing, Strategi, Politik, Pemilihan Presiden

\section{A. Pendahuluan}

Pemilihan Presiden secara langsung memberikan optimisme pada publik akan membaiknya kualitas kepemimpinan di Negara Republik Indonesia. Mekanisme pemilihan kepemimpinan yang dipilih secara langsung diyakini lebih baik dibandingkan dengan mekanisme yang tidak langsung (perwakilan), karena praktek sistem perwakilan dalam pemilihan Presiden dan kepala daerah, cenderung "membuka kran" terjadinya jual beli suara dan menghasilkan kepemimpinan yang bermasalah. ${ }^{1}$

Kesadaran akan pentingnya demokrasi dalam berpolitik bagi warga negara saat ini sangat tinggi. Hal ini dapat dilihat dari peran serta rakyat Indonesia dalam melaksanakan Pemilihan Umum baik yang diselenggarakan oleh pemerintah pusat maupun pemerintah daerah.

1 Kristina, Isu Strategis Dalam Penyelenggaraan Pilihan Kepala Daerah Langsung. Dalam Jurnal Dinamika VOL. 5 NO.1 Th.2005 
Terdapat fenomena baru dalam suasana demokrasi di Indonesia yang dimulai tahun 2004. Dalam Pemilihan Umum 2004 untuk pertama kalinya rakyat Indonesia diberi kebebasan untuk memilih presiden dan wakil presiden secara langsung. Setelah sukses dengan pemilihan presiden dan wakil presiden secara langsung tahun 2004 maka pada tahun 2005 bangsa Indonesia memulai era baru dalam pesta demokrasi yakni dengan diadakannya pemilihan kepala daerah (Pilkada) secara langsung.

\section{Latar Belakang}

Reformasi dilakukan bangsa Indonesia disegala sendi kehidupan negara, termasuk reformasi dibidang politik. Sebagaimana arti katanya sendiri, secara sederhana reformasi politik berarti membentuk kembali format politik agar lebih mencerminkan prinsip-prinsip demokrasi dan asas kedaulatan rakyat. Salah satu cara mewujudkan demokrasi itu sendiri adalah dengan diadakannya pemilihan umum (Pemilu). Pemilu dipercaya sebagai mekanisme demokrasi yang bertujuan menyegarkan kembali komitmen dan moralitas serta mengganti kepemimpinan secara demokratis.

Era reformasi di Indonesia membawa perubahan mendasar dalam mekanisme Pemilu yakni kembalinya sistem multi partai dari sistem tripartai pada era Soeharto yang lalu. Kini era kedaulatan rakyat benar-benar terwujud menggeser era kedaulatan elit yang pernah hadir sepanjang zaman Orde Baru. Tak hanya membawa perubahan mendasar dalam mekanisme pemilihan umum yakni kembalinya sistem multipartai, reformasi juga mampu menorehkan prestasi luar biasa dengan diadakannya pemilihan umum presiden dan wakil presiden serta wakil rakyat yang duduk di legislatif secara langsung.

Pemilu presiden secara langsung oleh rakyat merupakan suatu langkah dan bagian sangat penting serta fundamental dalam proses perubahan politik dewasa ini, suatu tranformasi struktur kekuasaan yang sangat mendasar dari bangunan kekuasaan yang otoritarian menuju suatu tatanan politik demokratis. Filosofi dari prinsip demokrasi adalah siapa yang akan menjadi pemenang kekuasaan. Pada tingkat apapun dan cabang kekuasaan yang manapun harus 
mendapat dari mandat dari rakyat, karena rakyat adalah pemegang kedaulatan tertinggi. ${ }^{2}$

Berdasar peraturan KPU Nomor 15 Tahun 2014, pengajuan pasangan calon presiden dan wakil presiden diusulkan oleh partai politik (parpol) atau gabungan partai politik peserta Pemilihan Umum Anggota Dewan Perwakilan Rakyat 2009 yang memperoleh minimal 20\% dari jumlah kursi DPR atau 25\% dari jumlah suara sah nasional. Oleh karena itu hasil pemilihan legislative merupakan modal untuk melaju ke pemilihan presiden dan wakil presiden.

Partai PDIP yang memperoleh 109 kursi di DPR atau presentasenya 18,95\% kursi DPR dalam Pileg 2014 tanpa ragu PDIP mengajukan Joko Widodo (Jokowi sebagai capres periode 2014-2019. Partai Golkar memperoleh 91 kursi atau $14,75 \%$, sementara partai Gerindra memperoleh 73 kursi di DPR atau 11,81\%. Partai PDIP dan Partai Golkar merupakan partai besar yang sudah lama sedangkan partai Gerindra merupakan partai baru.

Pada pemilu legislatif 2014 ini ada tiga partai yang memenuhi syarat untuk maju ke pemilihan presiden yaitu partai PDIP, Golkar dan Gerindra.Untuk bisa bisa maju menjadi presiden maka PDIP membangun suatu kekuatan politik dengan jalan mencari dukungan dengan partai-partai yang tidak memenuhi syarat untuk maju ke pemilihan presiden 2014. Begitu juga Gerindra juga membangun suatu kekuatan politik. Akhirnya terbentuk dua koalisi yang akan maju ke pemilu presiden yaitu Koalisi Merah Putih (KMP) yang mengusung Prabowo Subianto dari Partai Gerindra sebagai calon Presiden dan Joko Widodo (Jokowi) dari Koalisi Indonesia Hebat sebagai calon presiden yang berasal dari partai PDIP.

Pemilihan umum ini diikuti oleh dua pasang calon Presiden dan Wakil Presiden yaitu Prabowo Subianto, mantan Panglima Kostrad yang berpasangan dengan Hatta Rajasa, mantan Menteri Koordinator Bidang Perekonomian 20092014, serta Joko Widodo, Gubernur DKI Jakarta yang berpasangan dengan Jusuf Kalla, mantan Wakil Presiden Republik Indonesia periode 2004-2009. Pada tanggal 31 Mei 2014, Komisi Pemilihan Umum (KPU) menetapkan 2 pasang

2 Joko Utomo Hadibroto, "Strategi Komunikasi Politik SBY-MJK dalam Menggunakan Media Massa pada Pilpres putaran pertama 5 Juli 2004 di Surakarta"( Surakarta: FISIP UNS , 2005) Skripsi Ilmu Komunikasi, hlm. 5 
calon Presiden dan Wakil Presiden, serta melakukan pengundian nomor urut pada 1 Juni 2014.

Dinamika politik menitik beratkan pada bagaimana pola keterhubungan calon dan konstituen menjadi searah demi sebuah kepentingan atau kemenangan. Untuk memenangkan calon, dalam hal ini sebagai Presiden dan Wakil Presiden misalnya, dibutuhkan strategi agar masyarakat (pemilih) simpati dan akhirnya melabuhkan pilihannya pada calon bersangkutan. Hal ini barangkali umum terjadi pada pelaksanaan pemilahan umum di tingkat nasional di mana peran partai sangat urgen dalam melakukan agitasi dan propaganda. ${ }^{3}$

Strategi politik dirancang oleh masing-masing partai agar calon yang diusungnya dapat terpilih sesuai dengan kehendak masyarakat (konstituen). Partai satu dengan partai lainnya tentunya akan menjual (sell) program unggulannya sehingga konstituen tertarik. Strategi yang lain juga lumrah dilakukan dalam praktik pemilihan umum, misalnya mengkampanyekan keunggulan pasangan calon Presiden dan Wakil Presidennya dari pada calon-calon yang lain. ${ }^{4}$

Pemilihan umum ini akhirnya dimenangi oleh pasangan Joko WidodoJusuf Kalla dengan memperoleh suara sebesar 53,15\%, mengalahkan pasangan Prabowo Subianto-Hatta Rajasa yang memperoleh suara sebesar 46,85\% sesuai dengan keputusan KPU RI pada 22 Juli 2014. Presiden dan Wakil Presiden terpilih dilantik pada tanggal 20 Oktober 2014, menggantikan Susilo Bambang Yudhoyono. ${ }^{5}$

Di Kota Batam Pemilihan presiden (pilpres) pada hari Rabu tanggal 9 Juli 2014 membawa kemenangan pasangan calon presiden dan wakil presiden nomor urut dua, Joko Widodo dan Jusuf Kalla yang unggul di sepuluh kecamatan yang ada di Kota Batam yaitu di Kecamatan Batam Kota, Batuampar, Lubuk Baja, Bengkong, Sei Beduk, Sagulung, Batu Aji, Nongsa, Bulang dan Galang. Sedangkan probowo-hatta Rajasa hanya unggul di dua kecamatan, yakni

3 Maurice Duverger, Sosiologi Politik, Jakarta : Raja Grafindo Persada, 2010, hal. 16

4 Firmanzah, Marketing Politik: Antara Pemahaman dan Realitas Jakarta: Yayasan Obor Indonesia, 2008, hal. 7.

5 http://id.wikipedia.org/wiki/Pemilihan_umum_Presiden_Indonesia_2014 di akses pada hari minggu tanggal 5 Oktober 2014 pada pukul $9.18 \mathrm{Wib}$ 
Sekupang dan Belakang Padang. Keunggulan Prabowo-Hatta di dua kecamatan tersebut hanya terpaut selisih suara tak banyak, hanya 1.901 suara saja. $^{6}$

Melihat kenyataan diatas dimana pasangan Joko Widodo-Jusuf Kalla unggul di sepuluh Kecamatan dari 12 Kecamatan yang diada di Kota Batam membuat penulis tertarik untuk meneliti tentang strategi tim sukses Joko Widodo dan Jusuf Kalla dalam pemenangan pemilihan Presiden di Kota Batam pada tahun 2014.

\section{Rumusan Masalah}

Berdasarkan latar belakang masalah di atas maka rumusan masalah dalam penelitian ini yaitu "Bagaimana Marketing Politik Joko Widodo-Jusuf Kalla Pada Pemenangan Pemilihan Presiden Tahun 2014 di Kota Batam”?

\section{Batasan Masalah}

Pembatasan masalah dilakukan agar penelitian lebih terarah, terfokus, dan tidak menyimpang dari sasaran pokok penelitian. Oleh karena itu, penulis memfokuskan kepada pembahasan atas masalah pokok penelitian yaitu marketing politik tim sukses untuk memenangkan pasangan Joko Widodo-Jusuf Kalla pada pemilihan presiden tahun 2014 di Kota Batam dengan mengambil Kecamatan Sagulung, Kecamatan Batam Kota dan Kecamatan Sekupang sebagai sampel penelitian.

\section{Tujuan dan Manfaat Penelitian}

Wahid Wafa, http://batam.tribunnews.com/2014/07/10/pasangan-jokowi-jk-merajai-sepuluhkecamatan-di-batam, minggu 26 april 2015 
Dari permasalahan penelitian yang telah dirumuskan, maka tujuan dari penelitian ini adalah untuk mengetahui Marketing Politik Joko Widodo-Jusuf Kalla Pada Pemenangan Pemilihan Presiden Tahun 2014 di Kota Batam.

Manfaat dari kegiatan penelitian ini diharapkan berguna secara : Pertama, Secara Teoritis, Penelitian ini diharapkan dapat menambah wawasan ilmiah bagi peneliti khususnya tentang Marketing Politik Joko Widodo-Jusuf Kalla Pada Pemenangan Pemilihan Presiden Tahun 2014 di Kota Batam; Kedua, Terhadap Pendidikan, Diharapkan penelitian ini hendaknya menjadi bahan rujukan bagi mahasiswa dalam mempelajari Marketing Politik Joko Widodo - Jusuf Kalla Pada Pemenangan Pemilihan Presiden Tahun 2014 di Kota Batam; Ketiga, Terhadap Pemerintah, Hasil penelitian ini di harapkan dapat menjadi bahan masukan dan kajian bagi Pemerintah Kota Batam khususnya dalam Marketing Politik Joko Widodo-Jusuf Kalla Pada Pemenangan Pemilihan Presiden Tahun 2014 di Kota Batam, dan Keempat, Secara Praktis, Hasil penelitian ini dapat digunakan sebagai bahan kajian bagi pihak yang berwenang dalam rangka penyelenggaraan pemilihan umum baik ditingkat provinsi maupun ditingkat kota tentang marketing politik pemenangan kandidat Pada Pemilihan calon kepala daerah untuk masa yang akan datang di Kota Batam.

\section{Kerangka Teori}

\section{a. Marketing Politik}

Marketing politik adalah suatu cabang atau ranting ilmu sosial interdispliner, ilmu marketing dan ilmu politik seperti halnya dalam perpaduan antara percabangan ilmu sosial lainnya . namun yang jelas kedua cabang ilmu tersebut memiliki karakhteristik yang berbeda antara satu dengan yang lain. Ilmu marketing berangkat dari kondisi persaingan bagaimana suatu usaha memenangkan persaingan di pasar, agar produk lebih unggul dan kompetitif di bandingkan dengan para pesaingnya. Sementara ilmu politik adalah ilmu yang bertujuan untuk mencaiptakan tatanan masyarakat melalui sistematisasi perebutan kekuasaan. 
Secara hakiki, politik berkaitan dengan upaya untuk mendapatkan konotasi yang buruk dalam bahasa bahasa dunia. Namun yang jelas marketing politik adalah perkawinan silang yang menghasilkan studi baru dalam politik, dan ekonomi, Tidak bisa kita pungkiri antara politik dan ekonomi saling bergantung, tidak akan mampu menang dalam politik kalau tidak didukung oleh ekonomi yang matang. Dan sebaliknya tidak akan berjalan ekonomi ketika kondisi politik tidak aman, seperti peperangan, kekacauan yang menghancurkan manusia. ${ }^{7}$

Seiring dengan kemajuan teknologi informasi dan komunikasi, semakin terintegrasinya masyarakat global dan tekanan untuk menerapkan prinsip-prinsip demokrasi, institusi politik pun membutuhkan pendekatan alternatif untuk membangun hubungan dengan konstituen dan masyarakat luas Dalam konteks inilah marketing sebagai suatu disiplin ilmu yang berkembang dalam dunia bisnis diasumsikan berguna bagi institusi politik. Ilmu marketing biasanya dikenal sebagai sebuah disiplin yang menghubungkan produsen dan konsumen. Hubungan dalam marketing tidak hanya terjadi satu arah, melainkan dua arah sekaligus dan stimultan. Produsen perlu memperkenalkan dan membawa produk serta jasa yang dihasilkan kepada konsumen. ${ }^{8}$

Metode dan pendekatan yang terdapat dalam ilmu marketing dapat membantu institusi politik untuk membawa produk politik kepada konstituen dan masyarakat secara luas. Institusi politik dapat menggunakan metode marketing dalam penyusunan produk politik, distribusi produk politik kepada publik dan meyakinkan bahwa produk politiknya lebih unggul dibandingkan dengan pesaing. Penggunaan metode marketing dalam bidang politik dikenal sebagai marketing politik (political marketing). Dalam marketing politik, yang ditekankan adalah penggunaan pendekatan dan metode marketing untuk membantu politikus dan partai politik agar lebih efisien serta efektif dalam membangun hubungan dua arah dengan konstituen dan masyarakat. Hubungan ini diartikan secara luas, dari

7 Pangi Syawi Chaniago, Political Marketing, Lihat di http://www.pangisyarwi.com, diakses pada hari Minggu tanggal 7 Februari 2016 jam 8.15 Wib

8 Aima, Marketing Politik, lihat di http://teratae.blogspot.co.id/2011/12/marketing-politik.html , diakses pada hari Kamis Tanggal 12 Mei 2016 jam 21,10 Wib. 
kontak fisik selama periode kampanye sampai dengan komunikasi tidak langsung melalui pemberitaan di media massa. ${ }^{9}$

Menurut Firmanzah, dalam kondisi persaingan politik, masing-masing kontestan membutuhkan cara dan metode yang tepat untuk bisa memenangkan persaingan. Mengukur kemenangan dalam dunia politik dilakukan dengan melihat siapa yang keluar sebagai pemenang dalam pemilihan umum. Namun, kemenangan ini juga harus dikaji dan dianalisis dengan hati-hati mengingat perimbangan kekuasaan yang ada di antara partai-partai politik. ${ }^{10}$

Menurut O' Cass dalam Firmanzah (2008: 321), filosofi marketing memberikan arahan bagaimana kita bisa menerapkan ilmu marketing dalam dunia politik. Karena pada dasarnya ilmu marketing melihat bahwa kebutuhan konsumen (stakeholder) adalah hal terpenting sehingga perlu diidentifikasi dan dicari bagaimana memenuhi kebutuhan tersebut. Konsep marketing komersial berdasarkan pada premis bahwa semua perencanaan dan operasi perusahaan berorientasi pada pemuasan konsumen (stakeholder). ${ }^{11}$

Menurut Firmanzah, marketing politik adalah konsep permanen yang harus dilakukan terus-menerus oleh sebuah partai politik atau kontestan dalam membangun kepercayaan dan image publik. Membangun kepercayaan dan image ini hanya bisa dilakukan melalui hubungan jangka panjang, tidak hanya pada masa kampanye. marketing politik harus dilihat secara komprehensif.

Menurut Niffenneger dalam Firmanzah Proses marketing politik terlihat seperti bagan dibawah ini :

\section{Gambar 1.1}

\footnotetext{
9 Ibid

10 Firmanzah, Marketing Politik : Antara Pemahaman dan Realitas, Jakarta, Yayasan Obor Indonesia, 2008, hal. 147

11 Ibid, hal. 321
} 


\section{Bagan Proses Marketing Politik}

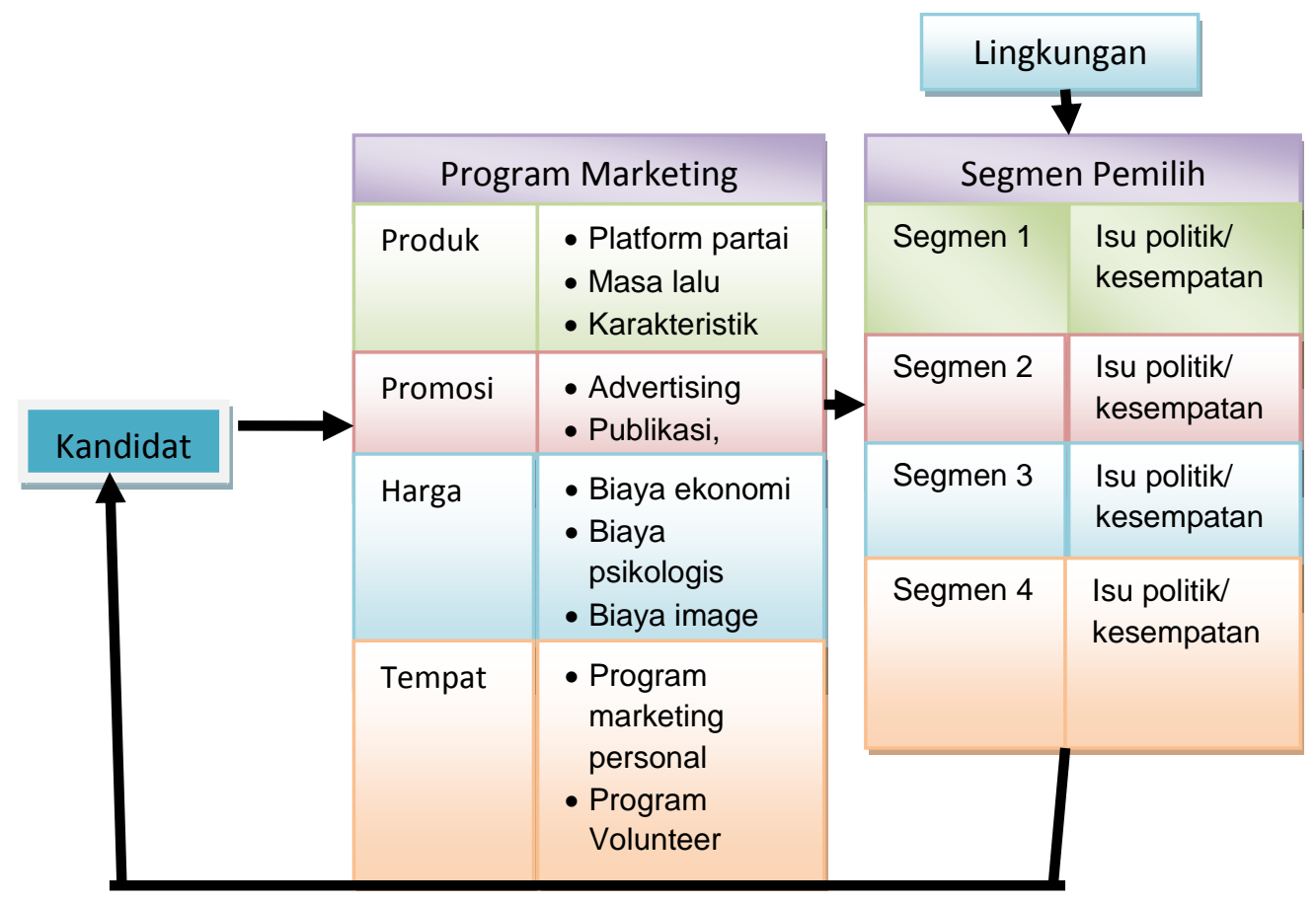

Sumber: Niffenegger dalam Firmanzah

Konsep 4P dalam marketing politik menjadi fokus pada penelitian ini, yang mana dari konsep 4P tersebut peneliti mengetahui bagaiman calon atau kandidat mampu melakukan strategi politik dengan baik dan tepat sasaran, namun sebelumnya mari kita ulas terlebih dahulu konsep 4P bauran marketing politik $^{12}$ :

\section{Product}

2. Promotion

3. Price

4. Place

\section{b. Pemenangan Joko Widodo-Jusuf Kalla}

Dalam Undang-Undang No. 42 Tahun 2008 tentang pemilihan Umum Presiden dan Wakil Presiden Pasal 9 mengatur tentang persyaratan calon presiden dan wakil presiden harus diusulkan oleh partai politik atau gabungan partai politik peserta pemilu yang memenuhi persyaratan perolehan kursi paling sedikit $20 \%$ dari kursi DPR (560 kursi) atau memperoleh 25\% dari suara sah nasional dalam

12 Ibid, hal. 200 
pemilu anggota DPR sebelum pelaksanaan Pemilu Presiden dan Wakil Presiden. Berpedoman pada perarturan perundang-undangan tersebut maka dalam Pilpres 2014 dapat dipastikan bahwa tidak ada partai politik yang bisa mengajukkan calon presden dan calon wakil presidenya sendiri, sehingga partai politik harus melakukan koalisi untuk bisa mengajukan capres dan cawapresnya. ${ }^{13}$

Partai PDI-Perjuangan sebagai partai pemenang pemilu hanya mendapatkan 18,95\% suara nasional mengusung Jokowi sebagai capresnya. Berbagai manufer politik dilakukan oleh para elit partai, diantaranya partai Golkar yang menjajaki koalisi dengan PDI-P serta dengan Gerindra melalui berbagai pertemuan dengan Jokowi dan Prabowo Subianto. Sehingga ada dua kandidat kuat calon presiden yaitu Joko Widodo Gubenur DKI Jakarta serta Prabowo Subianto Ketua Dewan Pembina partai Gerindra. Namun untuk mengusung mereka menuju pemilu presiden tetap harus menggunakan koalisi partai.

Koalisi Indonesia hebat mengusung Jokowi melakukan berbagai komunikasi politik untuk menyeleksi calon wakil presiden yang akan mendampingi Joko Widodo. Banyak nama calon yang diajukan untuk mendampingi Jokowi sebagai Calon wakil presiden. ${ }^{14}$ Di antaranya:

1. Basuki Tjahja Purnama (Ahok) Wakil Gubernur DKI Jakarta.

2. Mahfud MD Mantan Hakim Mahkamah Konstitusi.

3. Abraham Samad Ketua KPK.

4. Ryamizad Ryacudu Mantan KASAD.

5. Jusuf Kalla Mantan Wakil Presiden periode 2004-2009.

Pada tanggal 19 Mei 2014, PDI-P, Partai Nasdem, Partai Kebangkitan Bangsa dan Partai Hanura mendeklarasikan penetapan Jokowi dan Jusuf Kalla sebagai calon presiden dan calon wakil presiden di Gedung Joang 45, Menteng. Sementara itu pesaing pasangan Jokowi-JK yaitu Prabowo-Hatta juga telah mendeklarasikan diri. Pilpres 2014 berlangsung satu putaran setelah Partai Golkar

13 Cangara, Komunikasi Politik: Konsep Teori \& Strategi., Jakarta, Raja Grafindo Persada 2014, hal. 204

14 http://www.republika.co.id/berita/pemilu/menuju-ri-1/14/ 04 / 11 / n3 umy5- ini- daftar- namakandidat-cawapres-jokowi-versi-pdip diakses tanggal 23 oktober 2014, pukul 09:24 WIB 
memastikan tidak membentuk poros baru bersama Partai Demokrat. Dengan demikian, ada dua pasangan calon presiden dan calon wakil presiden yaitu Joko Widodo-Jusuf Kalla (Jokowi-JK) dan Prabowo Subianto dan Hatta Rajasa. Pasangan Jokowi-JK didukung oleh empat parpol dengan memperoleh dukungan 39,97 persen suara atau 207 kursi DPR. Sementara pasangan Prabowo-Hatta memperoleh dukungan 48,93 persen suara atau 292 kursi DPR. Berikut gambar komposisi koalisi partai dalam pemilu presiden 2014:

\section{Gambar 1.2}

\section{Komposisi Koalisi Pilpres 2014}

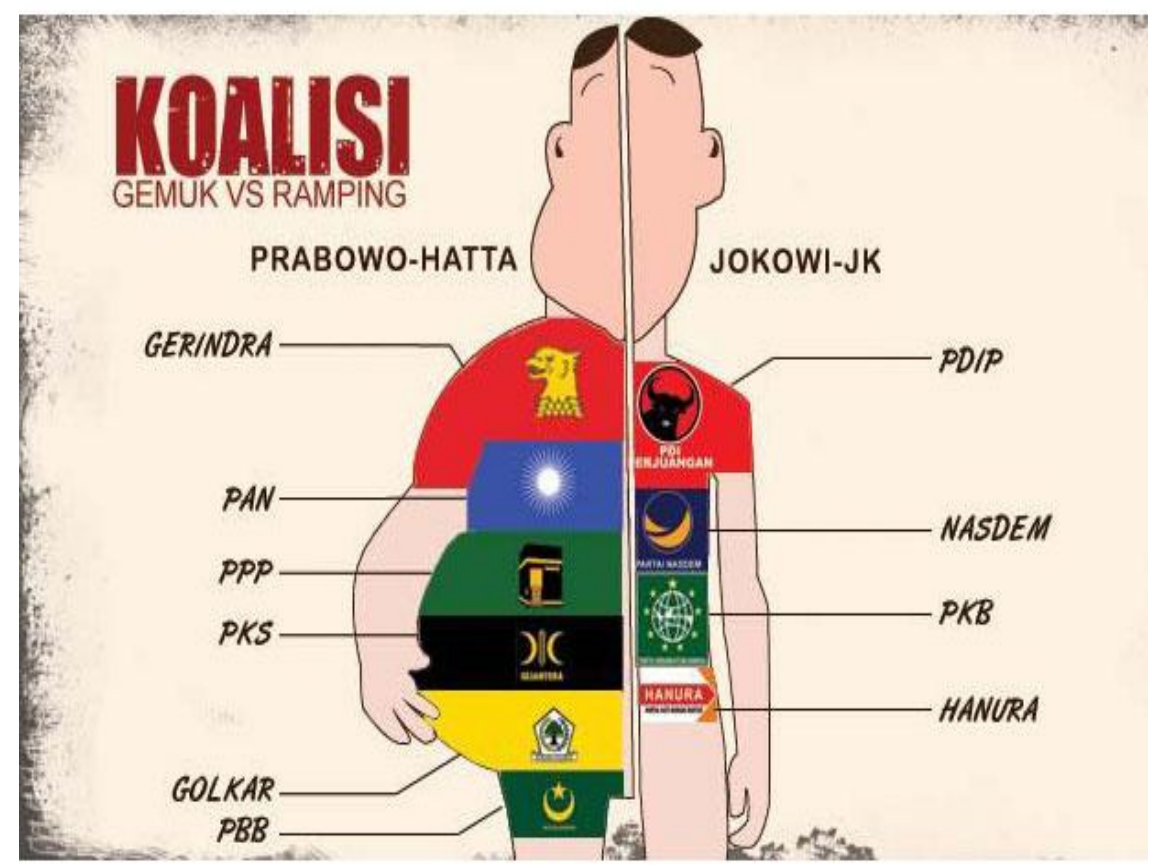

Sumber: http://acehimage.com/wp-content/uploads/2014/05/KOALISI

\section{c. Pemilihan Umum}

Pemilihan Umum adalah memilih seorang penguasa, pejabat atau lainnya dengan jalan menuliskan nama yang dipilih dalam secarik kertas atau dengan memberikan suaranya dalam pemilihan. ${ }^{15}$ Sedangkan, menurut Undang-undang Nomor 8 Tahun 2012 tentang Pemilihan Umum Anggota Dewan Perwakilan

15 Abu Nashr Muhammad Al-Iman, Membongkar Dosa-dosa Pemilu, Jakarta, Prisma Media, 2004, hal. 29. 
Rakyat, Dewan Perwakilan Daerah, dan Dewan Perwakilan Rakyat Daerah Pemilihan Umum adalah sarana pelaksanaan kedaulatan rakyat yang dilaksanakan secara langsung, umum, bebas, rahasia, jujur dan adil. ${ }^{16}$

Pemilih dalam pemilu disebut juga sebagai konstituen, di mana para peserta Pemilu menawarkan janji-janji dan program-programnya pada masa kampanye. Kampanye dilakukan selama diwaktu yang telah ditentukan menjelang hari pemungutan suara. Setelah pemungutan suara dilakukan, proses penghitungan dimulai. Pemenangan Pemilu ditentukan oleh aturan main atau sistem penentuan pemenang yang sebelumnya telah ditetapkan dan disetujui oleh para peserta, dan disosialisasikan ke para pemilih. Proses pemilihan umum merupakan bagian dari demokrasi.

\section{Metode Penelitian}

\section{a. Jenis Penelitian}

Penelitian ini menggunakan pendekatan kualitatif yaitu suatu proses penelitian dan pemahaman yang berdasarkan pada metodelogi yang menyelidiki suatu fenomena sosial dan masalah manusia. Dalam penelitian ini penulis menekankan sifat realitas yang terbangun secara sosial, hubungan antara peneliti dengan subyek yang diteliti.

\section{b. Lokasi Penelitian}

Untuk memperoleh data dan informasi yang dibutuhkan dalam penyusunan karya tulis ini, maka penelitian dilakukan di Kota Batam. Dengan keterbatasan waktu, tenaga dan dana maka penelitian ini hanya mengambil tiga Kecamatan saja yang mana tiga Kecamatan ini mewakili keseluruhan Kecamatan yang ada di Kota Batam. Kecamatan yang menjadi sampel dari penelitian ini yaitu Kecamatan Sagulung, Kecamatan Batam Kota dan Kecamatan Bengkong. Pemilihan lokasi penelitian tersebut didasarkan Karena pasangan JJokowi-JK jauh lebih unggul dibandingkan pasangan Prabowo Subianto-Hatta Rajasa dari Kecamatan yang lainnya di Kota Batam, sehingga penulis merasa tertarik untuk menelitinya. Disamping itu

16 Undang-undang Nomor 8 Tahun 2012 Tentang Pemilihan Umum Anggota Dewan Perwakilan Rakyat, Dewan Perwakilan Daerah, dan Dewan Perwakilan Rakyat Daerah 
dalam penulisan skripsi ini penulis juga melakukan studi kepustakaan (library research) di kantor Komisi Pemilihan Umum Daerah (KPUD) Kota Batam untuk mendukung pembahasan materi sesuai dengan karya

\section{c. Sumber Data}

Sumber data adalah Data Primer dan Data Sekunder.

\section{d. Teknik Pengumpulan Data}

Pengumpulan data dalam penelitian ini menggunakan teknik : (1). Observasi; (2). Wawancara; (3). Dokumentasi.

\section{Informan Yang Diwawancarai}

\begin{tabular}{|c|l|l|c|}
\hline No & \multicolumn{1}{|c|}{ NAMA } & \multicolumn{1}{|c|}{ JABATAN } & Jumlah \\
\hline 1 & Iwan Kurniawan & $\begin{array}{l}\text { Wakil Ketua DPD PDIP Prov. } \\
\text { Kepri }\end{array}$ & 1 orang \\
\hline 2 & Lis Darmansyah & Sekretaris DPD PDIPP Prov. Kepri & 1 orang \\
\hline 3 & Jamsir, ST & Ketua PAC PDIP Kota Batam & 1 orang \\
\hline 4 & Nuryanto, SH & Wakil Tim Pemenangan & 1 orang \\
\hline 5 & Ernawati & Sekretaris PAC PDIP Kota Batam & 1 orang \\
\hline 6 & Udin Sihaloho, SH & Keua PAC PDIP Kec. Benkong & 1 orang \\
\hline 7 & Faizil & $\begin{array}{l}\text { Sekretaris PAC PDIP Kec. } \\
\text { Bengkong }\end{array}$ & 1 orang \\
\hline 8 & Hj. Rekavenny & Ketua PAC PDIP Kec. Batam Kota & 1 orang \\
\hline 9 & M. Ali Usman NST & $\begin{array}{l}\text { Sekretaris PAC PDIP Kec. Batam } \\
\text { Kota }\end{array}$ & 1 orang \\
\hline 10 & Muchlis Jamal & Ketua PAC PDIP Kec. Sagulung & 1 orang \\
\hline 11 & Pardamaian S & $\begin{array}{l}\text { Sekretaris PAC PDIP Kec. } \\
\text { Sagulung }\end{array}$ & 1 orang \\
\hline & & Total & 10 orang \\
\hline
\end{tabular}

\section{B. Hasil dan Pembahasan}

\section{Strategi Pemenangan Jokowi-JK Pada Pemilihan Presiden Tahun 2014 di}

\section{Kota Batam}

Strategi merupakan penetapan sasaran dan tujuan jangka panjang sebuah perusahaan dan arah tindakan serta alokasi sumber daya yang 
diperlukan untuk mencapai sasaran dan tujuan. Dalam sebuah pertarungan politik yang menghubungkan antara pelaku politik atau politikus dengan pemilih pasti membutuhkan metode untuk melakukan pendekatan kepada pemilih.

Penelitian ini menggunakan teori marketing politik yang digagas oleh Firmanzah. Marketing politik yang ditekankan adalah penggunaan pendekatan dan metode marketing untuk membantu politikus dan partai politik untuk lebih efisien dan efektif dalam membangun hubungan dua arah dengan konstituen dan masyarakat. Hubungan ini diartikan secara luas, dari kontak fisik selama periode kampanye sampai dengan komunikasi tidak langsung melalui pemberitahuan di media massa.

Marketing politik bukan dimaksudkan untuk 'menjual' kontestan kepada publik, melainkan sebagai teknik untuk memelihara hubungan dengan publik agar tercipta hubungan dua arah yang langgeng Pada dasarnya political marketing adalah strategi kampanye politik untuk membentuk serangkaian makna politis tertentu dalam pikiran para pemilih. Serangkain makna politis yang terbentuk dalam pikiran para pemilih menjadi oreantasi perilaku yang akan mengarahkan pemilih untuk memilih kontestan tertentu. Makna politis inilah yang menjadi output penting political marketing yang menentukan pihak mana yang akan dicoblos oleh para pemilih.

Dalam Pemilihan Presiden tahun 2014 ada dua koalisi besar yaitu Koalisi Indonesia Hebat dan Koalisi Merah Putih. Koalisi Indonesia Hebat yang mengusung pasangan Jokowi-JK memenangkan pemilihan presiden 2014, tidak hanya secara nasional namun juga Kota Batam sebagai kota metropolitan yang memiliki kepadatan penduduk tinggi, sehingga kemenangan di Kota Batam memberikan pengaruh yang besar terhadap kemenangan secara nasional. Oleh karena itu tim pemenangan PDI-P Kota Batam memiliki strategi yang khusus dalam pemenangan Pemilu Presiden tahun 2014 yaitu berupa marketing politik dimana variable yang digunakan adalah : Produk yang ditawarkan, Promosi, Harga (Price), Tempat (Place) dan Segmentasi. Hasil perolehan suara pada Pilpres 2014 di Kecamatan Sagulung, Kecamatan Batam Kota dan Kecamatan Bengkong dapat dilihat pada tabel dibawah ini : 
Rincian Jumlah Perolehan Suara Pilpres Di Tiga Kecamatan Kota Batam Tahun 2014

\begin{tabular}{|c|l|c|c|c|c|c|}
\hline \multirow{2}{*}{ No } & KECAMATAN & \multirow{2}{*}{$\begin{array}{c}\text { DPT } \\
\text { (JIWA) }\end{array}$} & \multicolumn{2}{|c|}{ Yang Memilih } & \multirow{2}{\text{Suara}}{$\begin{array}{c}\text { Total } \\
\text { Tidak } \\
\text { Sah }\end{array}$} & $\begin{array}{c}\text { Yang } \\
\text { Memilih }\end{array}$ \\
\hline 1 & Sagulung & 118.883 & 33.442 & 41.770 & 334 & 75.546 \\
\hline 2 & Batam Kota & 117.588 & 31.612 & 45.129 & 290 & 77.031 \\
\hline 3 & Bengkong & 69.159 & 22.048 & 24.017 & 156 & 46.257 \\
\hline
\end{tabular}

Sumber : KPU Kota Batam Tahun 2014

\section{Penerapan Marketing Politik Jokowi-JK}

\section{a. Produk Yang Ditawarkan}

Dari perspektif political marketing Partai juga dapat dipandang sebagai produk politik. Pasalnya, Partai dengan berbagai atribut juga akan membentuk makna politik dalam kalangan pemilih tertentu. Banyak pemilih yang menjatuhkan pilihannya semata-mata karena faktor Partai, tanpa memperhatikan apa kebijakan yang ditawarkan dan siapa kandidat yang diajukan, hal ini terjadi saat Indonesia menganut sistem proporsional terbuka untuk pemilu sekarang yang mencontreng Partai dan calegnya.

Produk yang ditawarkan institusi politik Koalisi Indonesia Hebat ialah kandidat capres dan cawapres dimana pemilih akan dapat menikmati hasil dari produk tersebut setelah capres dan cawapres terpilih. Oleh karena itu kandidat yang akan dicalonkan harus orang yang tepat dan diterima oleh pemilih. Dalam produk yang ditawarkan ini yang dilihat adalah :

\section{1) Elektabilitas}

Berikut wawancara penulis dengan wakil ketua Dewan Pimpinan Daerah (DPD) PDI-P terkait dengan elektabilitas calon yang diusung yaitu :

“....Survey elektabilitas Jokowi mencapai $72 \%$ diakhir tahun 2013, serta popularitasnya mencapai 90\%, 72\% tingkat keterpilihan dari $90 \%$ persen kepopularitasannya hal ini sangat luar biasa....". 17 
Dari pernyataan yang disampaikan Iwan Kurniawan diatas, dapat dilihat bahwa dalam menentukan Joko Widodo (Jokowi) sebagai kandidat tim pemenangan melihat pada hasil survey dan riset. Pernyataan yang disampaikan Iwan Kurniawan juga diperkuat dari adanya dokumentasi hasil survey elektabilitas Jokowi seperti yang terlihat pada gambar dibawah ini :

\section{Grafik Tingkat keterpilihan Jokowi Pada Pilpres 2014}

\section{Jokowi Dicalonkan Sebagai ...}

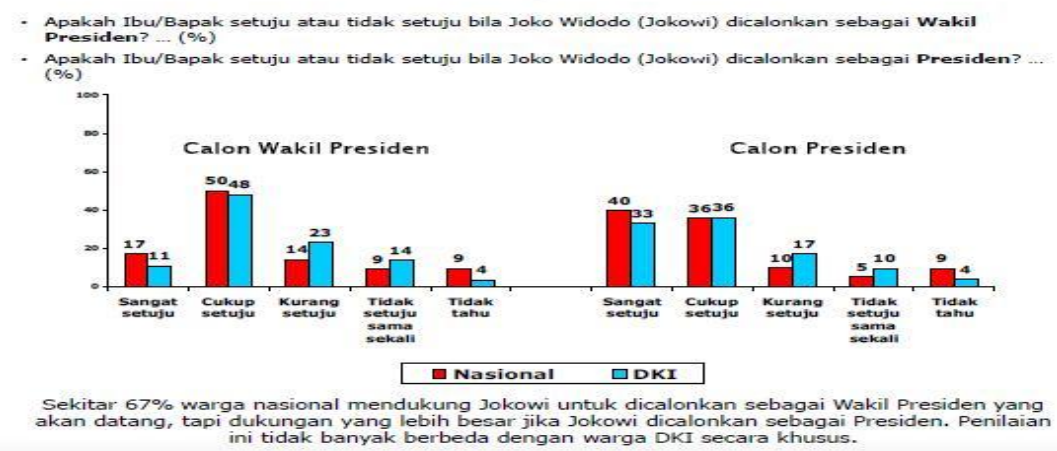

Dalam menentukan kandidat capres dan cawapres tidak hanya memperhatikan tingkat keterpilihan saja. Indonesia merupakan negara yang multikultur dengan wilayah yang sangat luas, sehingga kandidat capres dan cawapres harus bisa merangkul semua elemen masyarakat. Untuk itu Jokowi yang merupakan representatif Indonesia bagian Barat harus memiliki cawapres yang tidak hanya memiliki elektabilitas tinggi, namun juga merupakan representatif Indonesia bagian Timur.

Berikut wawancara penulis dengan ketua Tim Pemenangan Jokowi-Jusuf Kalla terkait dengan elektabilitas calon yang diusung yaitu :

“...terpilihnya Jusuf Kalla sebagai cawapres karena memiliki elektabilitas serta popularitas yang tinggi. Selain itu perwakilan wilayah harus terpenuhi dalam pemilihan kandidat, agar tidak menimbulkan gesekan dan merasa tidak diperhatikan. Jusuf Kalla direpresentasikan sebagai wakil dari Indonesia Timur, sedangkan Jokowi representasi dari Indonesia Barat. Karena bangsa Indonesia merupakan bangsa kesatuan 
serta berbeda-beda suku budaya maka keterwakilan wilayah harus dihitung..." 18

Berdasarkan wawancara diatas dapat dilihat bahwa elektabilitas dan popularitas akan mempengaruhi perolehan suara dari konstituen atau masyarakat pemilih. Selain itu perwakilan wilayah harus terpenuhi dalam pemilihan kandidat, agar tidak menimbulkan gesekan dan merasa tidak diperhatikan. Untuk itu Jokowi yang merupakan representatif Indonesia bagian Barat menggandeng cawapres yang tidak hanya memiliki elektabilitas tinggi, namun juga merupakan representatif Indonesia bagian Timur.

Salah satu penyebab unggulnya pasangan Jokowi-Jk pada pilres 2014 adalah karena elektabilitas kedua pasangan ini cukup tinggi dimata rakyat Indonesia disamping itu kedua tokoh ini merupakan gambaran keterwakilan wilayah Indonesia Bagian Timur untuk Jusuf Kalla dan Jokowi merupakan gambaran keterwakilan wilayah Indonesia Bagian Barat.

\section{2) Ideologi}

Produk politik tidak hanya ditentukan dari elektabilitas yang tinggi. Namun sesuai dengan marketing politik, produk politik juga ditentukan dari ideologi. Berikut wawancara penulis dengan sekretaris DPD PDIP Provinsi Kepulauan Riau terkait dengan ideologi calon yang diusung yaitu :

“....... Joko Widodo - Jusuf Kalla dengan platform ideology pancasila dan NKRI sebagai harga mati menjadikannya bisa merangkul persatuan dan kesatuan Indonesia, disamping itu Ia mencontohkan slogan "restorasi" atau "gerakan perubahan" yang kerap menjadi materi kampanye politik sebagai bentuk penerapan pemimpin yang berideologi.....". 19

18 Jamsir, ST., Selaku Ketua DPC PDIP Kota Batam dan Sekaligus ketua Pemenangan Joko Widodo - Jusuf Kalla Kota Batam, Wawancara Pada hari Rabu Tanggal 26 Agustus 2015 Jam 10.00 10.15 di ruangan Kantor DPC PDIP Kota Batam di Batam Centre.

19 Lis Darmansyah, Selaku Sekretaris DPD PDIP Provinsi Kepulauan Riau, Wawancara pada hari Selasa tanggal 25 Agustus 2015 jam 10.20 - 10.35 Wib di ruang kantor DPD PDIP Provinsi Kepri Batam Centre. 
Berdasarkan wawancara diatas dapat dilihat bahwa setiap pemimpin setiap pemimpin, baik di tingkat nasional maupun daerah, harus memiliki ideologi yang menuntun untuk membuat arah kebijakan yang pasti. Tanpa adanya ideologi, menurut Jokowi, seorang pemimpin akan berjalan tanpa arah. ideologi yang dianut di Indonesia adalah Pancasila, namun untuk mengejawantahkannya, masing-masing pemimpin memiliki caranya sendiri, ada yang lewat gerakan perubahan restorasi dan ada cara yang lain. Jokowi-JK mempunyai Ideologi jelas yaitu, berdaulat, berdikari dan berkepribadian. Berikut wawancara penulis dengan wakil ketua Tim Pemenangan Jokowi-JK terkait dengan ideologi calon yang diusung yaitu :

“....Dalam kampanye pilpres 2014 pasangan Jokowi-JK merancang sembilan program prioritas yang disebut Nawacita. Konsep ini disebut Jokowi berpedoman kepada Trisaktiyang dicetuskan Bung Karno, yakni berdaulat dalam politik, berdikari dalam ekonomi serta berkepribadian dalam budaya...". 20

Berdasarkan wawancara diatas dapat dilihat bahwa ideologi politik Jokowi adalah Nawacita yang berasal dari bahasa Sansekerta yakni Nawa yang berarti sembilan dan cita adalah tujuan. Jadi Nawacita secara harfiah adalah sembilan tujuan yang akan menjadi rujukan dari kinerja pemerintahan Jokowi-JK. Konsep Trisakti yaitu berdaulat dalam politik, berdikari dalam ekonomi dan berkepribadian dalam kebudayaan masih relevan untuk diterapkan saat ini oleh Jokowi. Nawacita ingin meneruskan cita-cita Trisakti yang putus di tengah jalan. Nawacita sesungguhnya secara substansial merupakan turunan dari ide Trisakti. Dalam Nawacita Jokowi mempunyai sembilan program yang ingin memperkuat kemandirian ekonomi dengan cara menggerakan ekonomi rakyat yang strategis dan memberikan perhatian kepada produk-produk Indonesia serta mendorong land-reform. Dalam bidang politik, Nawacita menginginkan terciptanya negara kuat dengan melakukan reformasi sistem dan penegakan hukum, memperkuat pertahanan maritim serta

${ }^{20}$ Nuryanto, SH., Selaku Bendahara DPC PDIP Kota Batam dan sekaligus Wakil Ketua Tim Pemenangan Jokwi - JK, Wawancara pada hari Rabu tanggal 26 Agustus 2015 jam 10.30 - 10.45 di ruangan kantor DPC PDIP Kota Batam di Batam Centre. 
negara tidak abai dalam membangun tata pemerintahan yang demokratis dan melindungi seluruh rakyat Indonesia. Dalam strategi kebudayaan, Nawacita secara jenius menyadari bahwa Indonesia dibentuk dari kolektivitas kebudayaan yang dibangun dari daerah-daerah, desa-desa kemudian menjadi Indonesia. Berkepribadian dalam kebudayaan dapat dicari dari khazanah kebudayaan Indonesia yang begitu luas bukan dari luar. Berikut wawancara penulis dengan Sekretaris DPC PDIP Kota Batam terkait dengan ideologi calon yang diusung yaitu :

“......menurut saya seorang calon presiden sudah memiliki ideologi dalam memimpin Negara kesatuan Republik Indonesia ini. Jokowi sebagai calon Presiden Juga sudah memiliki ideologi yaitu berdaulat, berdikari, dan berkepribadian yang lebih dikenal dengan konsep trisakti yang di cetuskan oleh Soekarno. Konsep ini dilahirkan Soekarno di tengah-tengah iklim revolusi Indonesia yang dijalankan di tengah gencetan dua kekuatan besar: Amerika Serikat dan Uni Soviet dan dua ideologi besar: liberalisme dan komunisme. Secara historis,Trisakti pada akhirnya macet di tengah jalan karena gejolak peristiwa 1965 yang menghancurkan mimpi-mimpi Soekarno terhadap pembangunan Indonesia". ${ }^{21}$

Berdasarkan wawancara diatas dapat dilihat bahwa seorang pemimpin baik di tingkat kota, kabupaten, provinsi, hingga nasional harus memiliki ideologi. Tanpa ideologi kepemimpinannya tidak akan mempunyai arah atau panduan yang jelas. Jadi salah satu sebab masyarakat di Kota Batam lebih percaya kepada pasangan Jokowi - JK untuk memimpin Negara Kesatuan Republik Indonesia adalah karena ideologinya sangat jelas dan sangat diterima oleh Rakyat Indonesia khususnya di Kota Batam..

\section{b. Promosi Yang Dilakukan}

Institusi politik, dalam hal ini Partai Demokrasi Indonesia Perjuangan (PDIP) dengan Koalisi Indonesia Hebat, pasti akan melakukan promosi sebagai bagian dari marketing politik, untuk dapat menjual produk politiknya. Pemilihan media untuk dijadikan sarana promosi menjadi

21 Ernawati, Selaku Sekretaris DPC PDIP Kota Batam, Wawancara pada hari Rabu tanggal 26 Agustus 2015 jam 11.30 - 11.45 di ruangan kantor DPC PDIP Kota Batam di Batam Centre. 
penting, karena tidak semua media efektif untuk mentrasfer pesan politik yang ingin disampaikan. Dalam Pilpres 2014, Komisi Pemilihan Umum telah memberikan waktu kepada kandidat untuk melakukan kampanye sebagai ajang untuk memperkenalkan pada pemilih. Banyak faktor penting yang mempengaruhi proses kampanye antara lain adalah juru kampanye, media, tempat dan waktu yang digunakan. Kampanye dapat diartikan sebagai proses komunikasi politik untuk mendekatkan kandidat dengan pemilih. Untuk memperkenalkan visi dan misi kandidat, kampanye tidak bisa dilakukan dalam waktu yang singkat karena harus bisa memberikan pemahaman kepada pemilih.

Berikut wawancara penulis dengan ketua PAC PDIP Kecamatan Bengkong Kota Batam terkait dengan promosi yang dilakukan yaitu :

“...Juru kampanye menjadi syarat di KPU untuk menyampaikan kepanitiaan. Untuk juru kampanye sendiri tim sudah memiliki patokan mereka adalah tokoh nasional yang berasal dari internal partai koalisi, salah satunya adalah Surya Paloh tokoh nasional dari Partai Nasional Demokrat (Nas Dem) yang merupakan juru kampanye Nasional yang datang ke Kota Batam untuk mempromosikan pasangan calon presiden yang di usung oleh PDIP, Jamsir, Nuryanto (cak Nur) dan yang lainnya juga merupakan juru kampanye yang diakui secara Nasional”. ${ }^{22}$

Berdasarkan wawancara diatas dapat dilihat bahwa untuk mempromosikan suatu produk diperlukan seorang juru promosi yang telah diakui secara nasional yang bertugas untuk menyampaikan kelebihan dan keunggulan produk tersebut dengan produk yang lain. Dalam hal promosi produk politik dimana pasangan Jokowi-JK adalah merupakan produk politik dari PDIP yang harus dijual ketengah-tengah masyarakat kota Batam agar masyarakat Kota Batam tertarik dengan pasangan tersebut. Disinilah fungsi peran juru kampanye yaitu untuk menarik masa dan menarik dukungan masa tersebut.

\section{Baliho Jokowi-JK yang terpampang seberang jalan Depan}

22 Udin Sihaloho, Selaku ketua PAC PDIP Kecamatan Bengkong Kota Batam, Wawancara pada hari Rabu tanggal 26 Agustus 2015 jam 12.00 - 12.15 di ruangan kantor PAC PDIP Benkong Sadai Kota Batam. 


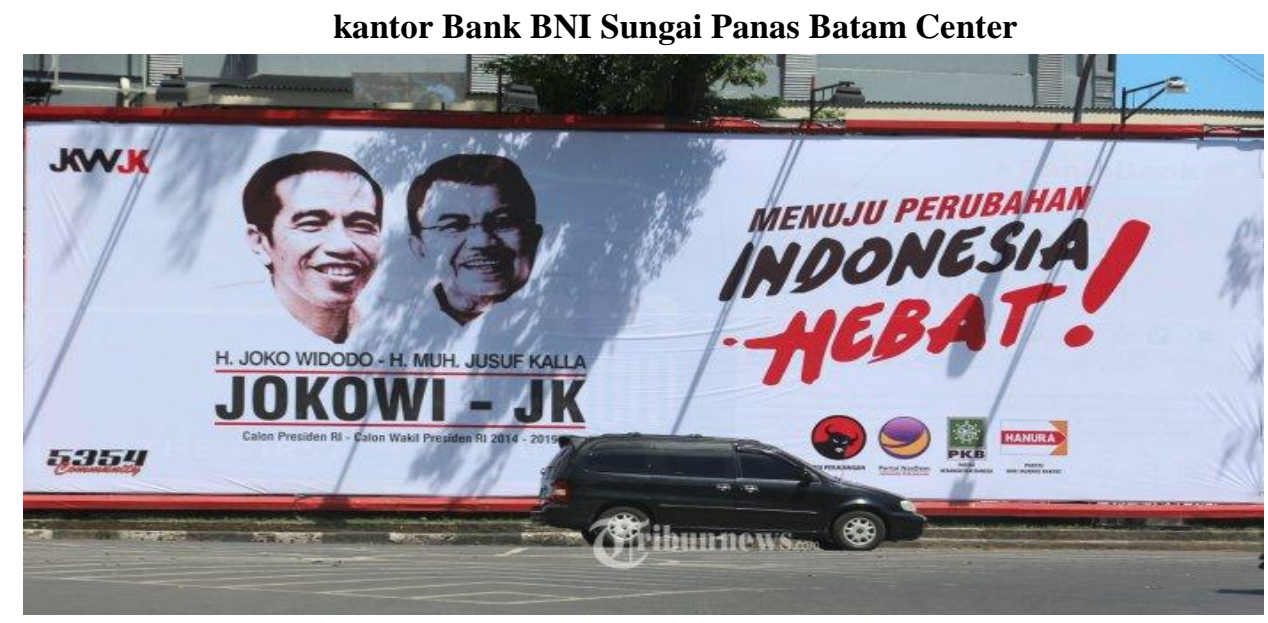

Baliho yang terpasang di pinggir jalan depan restoran Golden Prawn Bengkong

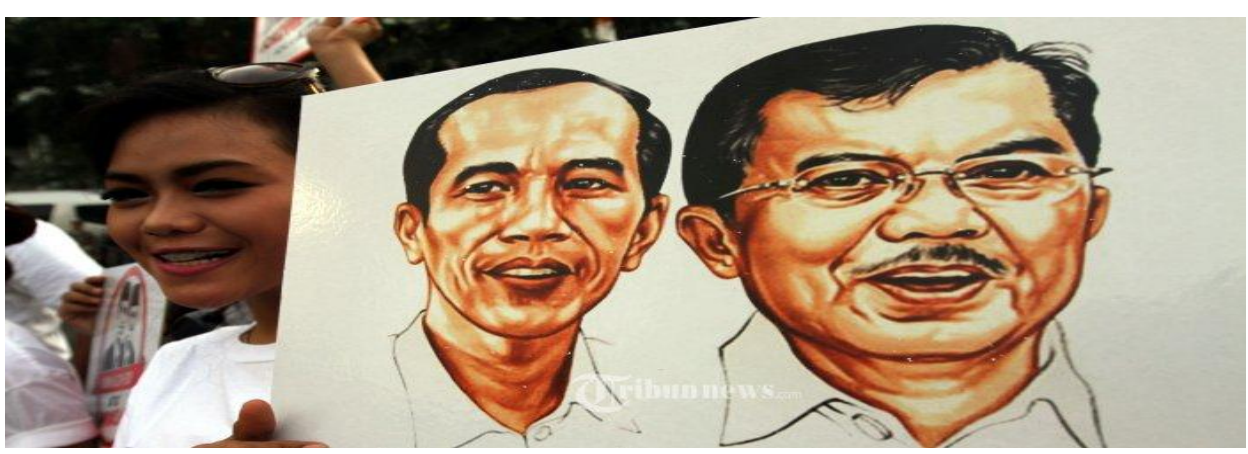

Baliho yang terpasang di atas ruko yang sedang Dibangun di samping Batam Centre Hotel

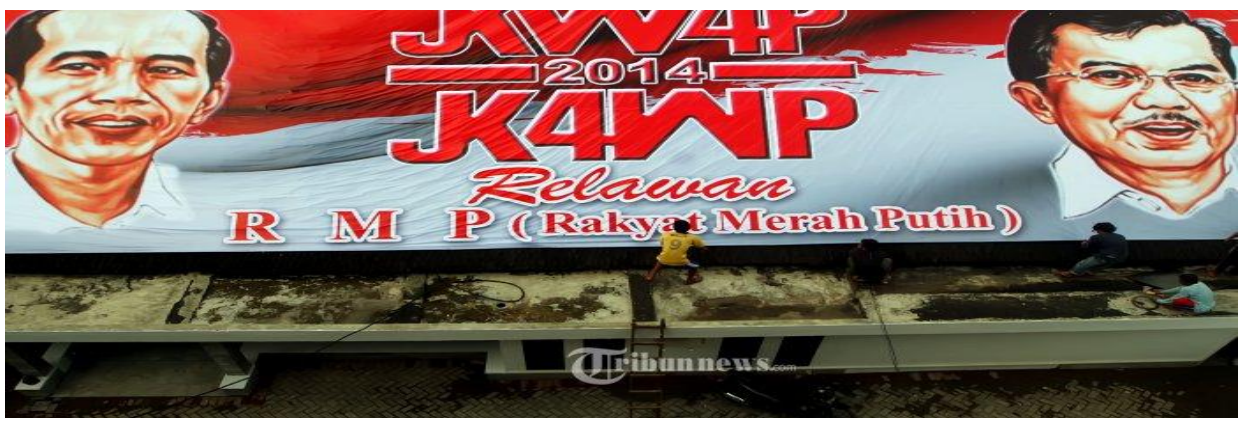

Baliho yang berada di pinggir jalan raya ini strategis untuk dilihat oleh masyarakat yang melalui jalan tersebut. Dalam meletakkan media 
untuk kampanye, tim pemenangan juga memperhatikan tempat yang digunakan. Tempat yang strategis akan mebuat pesan yang ingin disampaikan menjadi lebih mudah untuk diterima oleh masyarakat. Dalam baliho di atas mengandung pesan tim pemenangan mohon doa restu atas pencalonan Jokowi-JK untuk mengemban amanah rakyat Indonesia tahun 2014-2019.

Dalam berkampanye permasalahan tidak hanya pada media yang digunakan untuk memperkenalkan kandidat pada pemilih. Namun cara yang digunakan untuk berkampanye juga penting untuk diperhatikan. Kampanye sebagai media untuk mempromosikan kandidat capres dan cawapres harus memiliki integritas, sehingga dapat dipercaya oleh publik. Salah satu cara yang efektif dalam promosi institusi politik adalah dengan memperhatikan masalah yang dihadapi sebuah komunitas dimana institusi politik itu berada. Dengan demikian pemilih akan dapat merasakan keberadaan dari produk politik yang dipromosikan.

\section{c. Harga (Price) Jual}

Dalam marketing politik untuk memperkenalkan Jokowi-JK pada pemilih ada harga yang harus dibayar untuk mencapai tujuan yang diinginkan. Harga dalam proses marketing politik tidak hanya pada harga ekonomi saja, namun harga secara psikologis hingga citra secara nasional menjadi harga yang harus dibayar.

Pada proses kampanye untuk mendekatkan Jokowi-JK pada pemilih di Kota Batam pasti memerlukan biaya yang sangat besar. Pada proses kampanye untuk mendekatkan Jokowi-JK pada pemilih di Kota Batam memerlukan biaya yang sangat besar. Dalam pemilu 2014 tim pemenangan membuka rekening gotong royong sebagai budaya baru demokrasi Indonesia. Budaya baru dalam demokrasi di Indonesia harus dijaga, pembiayaan kampanye tidak lagi top down tapi sekarang dengan cara buttom up. 
Pemahaman harga dalam konteks politik dapat dimodifikasi sebagai kemampuan dan kesedian anggota partai dan konstituen dalam memberikan pengorbanan material dan beban psikologis untuk disumbangkan kepada partai. Makin tinggi kesediaan berkorban berarti partai politik memiliki harga yang kompetitif, artinya produk diminati walaupun dengan pemberian pengorbanan material dan immaterial bagi pendukungnya.

Memenangkan pilpres 2014 membutuhkan analisis untung rugi dan kalkulasi ekonomi yang akurat yakni bagaimana mengurangi resiko biaya politik yang tinggi. Efisiensi penting dalam memenangkan pilpres 2014, tim kampanye pasangan Jokowi-JK harus memikirkan strategi dan efisiensi dengan matang, bagaimana mengurangi resiko dan meningkatkan keuntungan/manfaat. Hal ini diperlukan agar pilpres 2014 dapat dilaksanakan secara efisien bukan sekedar efektif dengan mengurangi kerugian dan kemubaziran yang timbul akibat biaya politik (kampanye) dan ongkos politik dari pasangan Jokowi-JK yang akan semakin besar apabila tim pemenang pasangan tidak dapat mengatur strategi.

Biaya Politik dalam marketing politik menyangkut banyak hal mulai dari ekonomi, psikologis, sampai pada citra. Harga ekonomi yakni biaya yang dikeluarkan dalam kampanye politik kandidat dan biaya yang didapat pemilih dari kandidat. Harga psikologis, yakni kenyamanan pemilih dengan latar belakang (agama, ras pendidikan, etnis,dll) rasa yang didapatkan kandidat dan pemilih. Harga citra, yakni berkaitan dengan kepuasan pemilih terhadap citra yang dimiliki kandidat

Untuk mencapai tujuan yang diharapkan dalam politik yakni kemenangan dalam pilpres 2014 diperlukan pengorbanan yang cukup besar. Begitu juga dengan pasangan Jokowi-JK dalam usaha untuk mencapai kememnangan dikota Batam masing kandidat dari pasangan ini telah mengeluarkan biaya yang sangat tinggi untuk membentuk citra dari pasangan Jokowi-JK dan akhirnya pada pilpres 2014 di Kota Batam Pasangan Jokowi-JK jauh lebih unggul dalam perolehan suara disetiap 
Kecamatan yangada di Kota Batam kecuali dikecamatan Sekupang dan Belakang Padang.

\section{d. Tempat (Place) Yang Diprioritaskan}

Tempat (Place) diartikan sebagai distribusi jaringan yang berisi orang dan institusi yang terkait dengan aliran produk politik kepada masyarakat secara luas, sehingga masyarakat dapat merasakan dan mengakses produk politik dengan lebih mudah. Penempatan dalam konteks politik dapat diartikan sebagai lokasi atau distribusi yang menyangkut pada persoalan dimana produk politik akan disosialisasikan kepada masyarakat dan bagaimana produk tersebut dapat sampai kepada pemilih.

Pemilihan tempat dalam kampanye memiliki peran yang penting, karena kampanye harus menyentuh semua lapisan masyarakat. Tempat berkaitan erat dengan cara hadir kandidat untuk berkomunikasi dengan pemilih. Dalam melakukan kampanye di Kota Batam Jokowi-JK memiliki keterbatasan waktu sesuai dengan jadwal yang diberikan oleh KPU (Komisi Pemilihan Umum) yaitu hari Kamis tanggal 26 Juni 2014. Semula yang direncanakan dating adalah Jokowi namun Jokowi berhalangan datang. Akhirnya tim sukses menggantinya dengan Jusuf Kalla pada hari dan tanggal yang sama. Waktu yang disediakan untuk kampanye di Kota Batam sangat singkat. Oleh karena itu, tim pemenangan harus bisa mengatur daerah-daerah yang menjadi prioritas untuk dikunjungi.

Pemilihan tempat kampanye di Kota Batam memang harus dipikirkan secara matang. Pemilihan daerah mana yang harus dikunjungi bukan permasalahan yang sederhana. Kota Batam adalah wilayah yang luas dan kepadatan penduduk tinggi, namun menjadi perebutan untuk dimenangkan dalam pilpres.

Berikut wawancara penulis dengan ketua PAC PDIP Kecamatan Sagulung Kota Batam terkait dengan waktu kampanye di Kota Batam :

“...Masalah penetuan waktu dan tempat, kami tidak menentukan sendiri, sebab sudah diatur jadwalnya dengan KPUD Kota Batam dan juga tidak bisa membuat keputusan sendiri harus ditempatkan di Kecamatan Sagulung. Saya selaku Tim Pemenang Jokowi-JK untuk Kecamatan 
Sagulung hanya bersifat menaati peraturan begitu juga dengan tim pemenangan dari Kecamatan-kecamatan lain di Kota Batam. Jangan sampai melanggar apa yang sudah dibuat, sebab dapat merusak citra kandidat pasangan kami apabila tidak taat peraturan. Jadi penentuan tempat dan waktu kampanye kami sesuai jadwal dari KPUD Kota Batam". ${ }^{23}$

Berdasarkan wawancara diatas dapat dilihat bahwa, tim pemenang dalam penentuan hari kampanye, mengikuti jadwal yang telah ditetapkan oleh KPUD Kota Batam. Jadi tim kampanye tidak bisa menetapkan sendiri kapan kampanye dilaksanakan dan harus taat pada aturan yang telah ditetapkan

\section{e. Segmentasi}

Segmentasi dalam marketing politik untuk memperkenalkan Jokowi-JK sangat penting dilakukan. Pemetaan ini dilakukan mengingat kandidat harus hadir dalam berbagai karakteristik pemilih. Kehadiran kandidat diartikan sejauhmana kandidat bisa menjawab permasalahan yang dihadapi dimasing-masing lapisan masyarakat. Masing-masing segmen memiliki ciri dan karakteristik yang berbeda, sehingga pendekatan yang dilakukan harus dibedakan. Kesesuaian teknik berkampanye dalam setiap segmen menjadi sangat penting. Karena apabila cara yang digunakan itu salah maka hasil yang didapat tidak akan sesuai dengan yang diharapkan.

Setiap kelompok masyarakat tersusun dari individu-individu yang memiliki ciri, kepribadian, harapan, aspirasi dan tujuan yang kurang lebih sama. Tujuan mereka untuk mendapatkan kehidupan yang lebih sejahtera. Hal ini memudahkan kandidat dalam mengkomunikasikan pesan politik yang akan menjadi progam kerja. Jokowi harus bisa diterima oleh semua pihak dengan berbagai pendekatan.

Hadirnya kandidat dalam setiap segmen pemilih menjadi sangat penting karena kandidat harus secara langsung mengetahui keluhan dari rakyat yang akan dipimpinnya. Dengan demikian rakyat akan merasakan

${ }^{23}$ Muchlis Jamal, Selaku Ketua PAC PDIP Kecamatan Sagulung Kota Batam, Wawancara pada hari Rabu tanggal 26 Agustus 2015 jam 16.00 - 16.15 Wib di ruangan kantor PAC PDIP Kecamatan Sagulung Kota Batam. 
kehadiran kandidat sebagai bagian dari rakyat itu sendiri. Tidak ada segmen pemilih yang menjadi prioritas utama, atau segmen yang dipinggirkan. Kehilangan suara di salah satu segmen akan berdampak fatal dalam perolehan suara secara keseluruhan. Sementara isu politik yang dibawa, akan membuat pemilih menjadi tertarik untuk memberikan suaranya terhadap kandidat. Pada dasarnya kandidat harus membawa isu yang bisa memberikan kesejahteraan bagi pemilih.

Berikut wawancara penulis dengan ketua Tim Pemenangan Jokowi-JK untuk Kota Batam terkait dengan segmentasi pemilih :

“... Grand design dari strategi pemenangan adalah dengan merubah pola kampanye konvensional yang berorasi, mendirikan panggung kampanye, teriak-teriak satu arah dengan kampanye yang lebih interaksi dengan calon pemilih dan kandidat. Jadi, harus merubah pola kampanye. Salah satunya dengan door to door. Kenapa grand design kampanye harus dirubah, Karena kampanye di lapangan sudah tidak efektif lagi. Hal ini terlihat saat Pileg partai memiliki harapan yang besar bahwa Jokowi-Jusuf Kalla dapat memenangkan PDI-P dalam pemilu tahun 2014 ". ${ }^{24}$

Berdasarkan wawancara diatas grand design strategi pemenangan dari tim pemenangan perlu merubah pola kampanye konvensional dengan pola kampanye langsung mempertemukan kandidat dengan pemilih. Namun grand design tim pemenangan tidak bisa selalu dilaksanakan. Hal ini karena adanya keterbatasan waktu kampanye Jokowi sehingga tidak dapat hadir di Kota Batam. Walaupun tidak bisa hadir di Kota Batam namun tim sukses berupaya untuk mendatangkan Jusuf Kalla sebagai calon wakil Presiden yang berpasangan dengan Jokowi pada hari Kamis tanggal 26 Juni 2014. Dengan kedatangan calon wakil Presiden tim pemenangan harus memperhitungkan dengan cermat daerah yang dikunjungi langsung oleh Jusuf Kalla, dengan daerah yang dikunjungi dengan juru kampanye.

\section{Kesimpulan dan Saran}

24 Jamsir, ST., Selaku Ketua DPC PDIP Kota Batam dan Sekaligus ketua Pemenangan Joko Widodo - Jusuf Kalla Kota Batam, Wawancara Pada hari Rabu Tanggal 26 Agustus 2015 Jam 10.00 10.15 di ruangan Kantor DPC PDIP Kota Batam di Batam Centre. 
Ada beberapa simpulan dan saran dalam penelitian ini, diantaranya : Pertama, Untuk Pemerintahan Kota Batam disarankan agar menekankan kepada setiap partai yang ada di Kota Batam untuk memberikan pendidikan politik kepada masyarakat agar masyarakat mengerti dengan politik. Sehingga diharapkan kedepannya masyarakat memahami betapa pentingnya berpolitik agar masyarakat dapat berpartisipasi aktif dalam setiap pesta demokrasi dan pembangunan di Kota Batam; Kedua, Untuk Partai Politik PDIP disarankan agar dapat menjaga kepercayaan masyarakat, sehingga masyarakat mau berpartisipasi dalam menunjang program-program yang telah dicanangkan oleh partai khususnya dalam upaya membangun sistem demokrasi yang baik di Kota Batam pada pemilihan presiden yang akan dating; Ketiga, Untuk Masyarakat disarankan agar selalu untuk ikut berpartisipasi aktif dalam setiap penyelenggaran politik, pilihlah sesuai dengan hati nurani, menolak dipengaruhi oleh pihak-pihak tertentu dengan janji memberikan imbalan dalam bentuk apapun dan jangan memilih golput, karena golput itu adalah merupakan suatu kesalahan besar bagi masyarakat dan akan merugikan masyarakat juga secara tidak langsung.

\section{Daftar Pustaka}

\section{A. Buku}

Abu Nashr Muhammad Al-Iman, Membongkar Dosa-dosa Pemilu, Jakarta, Prisma Media, 2004.

Anman Nursal, Political Marketing, Strategi Memenangkan Pemilu sebuah pendekatan baru kampanye Pemilihan DPR, DPD, Presiden, Jakarta, Gramedia, 2004.

Bogdan dan Biklen, Qualitative Research For An Introduction The Teory And Method, London. 1982

Cangara, Komunikasi Politik: Konsep Teori \& Strategi., Jakarta, Raja Grafindo Persada 2014.

Cravens, David W., Strategic Marketing (Fifth Edition). USA: Mc-Graw Hill, 2000. Firmanzah, Marketing Politik: Antara Pemahaman dan Realitas Jakarta: Yayasan Obor Indonesia, 2008. 
, Marketing Politik; Antara Pemahaman dan Realita, Jakarta: Yayasan

Obor Indonesia, 2007.

Haryatmoko, Etika Politik dan Kekuasaan Jakarta: Penerbit Buku Kompas, 2003

Masri Singarimbun dan Sofian Effendi, Metode Penelitian Survei, Jakarta, LP3ES, 1989.

Maurice Duverger, Sosiologi Politik, Jakarta : Raja Grafindo Persada, 2010

Moleong, Lexy, Metodologi Penelitian Kualitatif, Bandung, Remaja Rosdakarya, 2006.

Nasution, Metode Research : Penelitian Ilmiah, Jakarta, Bumi Aksara, 2003.

Richard Harker, dkk. (Habitus x Modal + = Praktek) Pengantar Paling

Komprehensif kepada Pemikiran Pierre Boudieu, Yogyakarta, Jalasutra, 2009.

Sugiyono, Metode Penelitian Kuantitatif, Kualitatif, Dan $R \& D$, Bandung: Alfabeta, 2012.

, Statistika Untuk Penelitian, Cetakan Ketujuh, Bandung, Alfabeta. 2006.

Sutopo, H.B. Metodologi Penelitian Kualitatif. Surakarta : UNS Press, 2002.

\section{B. Undang-undang}

Undang-undang Nomor 8 Tahun 2012 Tentang Pemilihan Umum Anggota Dewan Perwakilan Rakyat, Dewan Perwakilan Daerah, dan Dewan Perwakilan Rakyat Daerah

Undang-undang Nomor 42 Tahun 2008 Tentang Pemilihan Umum Presiden dan Wakil Presiden

\section{Makalah, Karya Ilmiah, Jurnal, Website}

Agus Satmoko Adi, Lihat di https://www.scribd.com/doc/254127001/StrategiPemenangan-Jokowi-JK-Pada-Pemilu-Ppresiden- 2014 - StudiPada-Tim-Pemenangan-Koalisi - Indonesia-Hebat-Jawa-Timur. diakses pada hari Jumat tanggal 13 Mei 2016 jam 22.15 Wib.

Aima, Marketing Politik, lihat di http://teratae.blogspot.co.id/2011/12/marketingpolitik.html, diakses pada hari Kamis Tanggal 12 Mei 2016 jam 21,10 Wib.

http://www.republika.co.id/berita/pemilu/menuju-ri-1/14/04/ 11 / n3 umy5- inidaftar-nama- kandidat-cawapres-jokowi-versi-pdip diakses tanggal 23 oktober 2014, pukul 09:24 WIB.

Joko Utomo Hadibroto, "Strategi Komunikasi Politik SBY-MJK dalam Menggunakan Media Massa pada Pilpres putaran pertama 5 Juli 2004 
di Surakarta"( Surakarta: FISIP UNS , 2005) Skripsi Ilmu Komunikasi, hlm. 5.

Kristina, Isu Strategis Dalam Penyelenggaraan Pilihan Kepala Daerah Langsung. Dalam Jurnal Dinamika VOL. 5 NO.1 Th.2005.

Pangi Syawi Chaniago, Political Marketing, Lihat di http:_/_www. Pangisyarwi .com, diakses pada hari Minggu tanggal 7 Februari 2016 jam 8.15 Wib.

Rauf, Maswadi. Perkembangan UU Politik Pasca Amandemen UUD 1945. Makalah yang disajikan dalam Seminar dan Lokakarya Pembangunan Hukum Nasional VIII yang diselenggarakan oleh Badan Pembinaan Hukum Nasional di Denpasar, Bali, pada tanggal 14-18 Juli 2003.

Saldi Isra, Jurnal Konstitusi Pusat Studi Konstitusi Universitas Andalas (PUSAKO): Pemilihan Presiden Langsung dan Problematik Koalisi Dalam Sistem Presidensial. (Jakarta: Mahkamah Konstitusi RI, 2008), Volume II No. 1 Edisi Juni 2009.

Wikpedia, Lihat di http://id.wikipedia.org/wiki/Pemilihan_umum_Presiden Indonesia_2014 di akses pada hari minggu tanggal 5 Oktober 2014 pada pukul $9.18 \mathrm{Wib}$. 